\title{
Pharmaciana
}

Vol.11, No.3, Nov 2021, Page. 385-393

ISSN: 2088 4559; e-ISSN: 24770256

\section{Accelerated stability test of snakehead fish and kelulut honey ointment with CMC-Na as a binder}

\author{
Wintari Taurina*, Mohamad Andrie, Nur Firdiena Titian Ratu \\ Department of Pharmacy, Faculty of Medicine, \\ Tanjungpura University, Pontianak, Indonesia \\ Jl. Prof. Dr. H. Hadari Nawawi, Pontianak, West Kalimantan, Indonesia
}

\begin{abstract}
The extract of snakehead fish (Channa striata) and kelulut honey (Heterotrigona itama) ointment was proven to have activity in wound healing. However, previous studies showed instability in the ointment as indicated by the occurrence of phase separation. This study used CMC-Na (Carboxymethyl Cellulose Sodium) with a concentration of 3\% (F1), 4.5\% (F2), and 6\% (F3) as a binder. The stabilizer was added to increase the stability of the ointment preparation by binding to the aqueous phase and preventing it from leaving the ointment base. The test was carried out with the accelerated stability method at a temperature of $40^{\circ} \pm 2^{\circ} \mathrm{C}$ and a humidity of $75 \% \pm 5 \%$ for 28 days. The evaluation includes organoleptic tests, homogeneity, spreadability, adhesion, and protection power. The results showed that CMC-Na increased the stability of the ointment. The data obtained show that the higher the CMC-Na concentration used, the higher the consistency and adhesion were, but the lower the spreadability of the preparation. The results of the average spreadability and adhesion power for formulation 1 were $5.09 \mathrm{~cm}$ and 1797.33 seconds, formulation 2 were $4.42 \mathrm{~cm}$ and 1798.33 seconds, and formulation 3 were $3.69 \mathrm{~cm}$ and 1799 seconds. The results of the One-Way ANOVA showed that all formulations experienced a significant decrease in adhesion and increase in spreadability during 28 days of storage. The best ointment that meets the physical stability criteria is shown by the CMC-Na 3\% (F1) formulation, with a soft texture, homogeneous, a good spreadability $(5-7 \mathrm{~cm})$, a good adhesion (more than 4 seconds), and a good protective power for 28 days of testing.
\end{abstract}

Keywords: ointment, CMC-Na, snakehead fish extract, kelulut honey, accelerated stability

\footnotetext{
*Corresponding author:

Wintari Taurina

Department of Pharmacy, Faculty of Medicine, Tanjungpura University

Jl. Prof. Dr. H. Hadari Nawawi, Pontianak, West Kalimantan, Indonesia

Email: wintari.taurina@gmail.com
} 


\section{INTRODUCTION}

Ointments are semisolid preparations as an external medicine that are easy to apply. The function of ointments is as a drug carrier in skin treatment, skin lubricants, and skin protectors. The ointment must meet basic qualities, stable, soft, easy to use, a suitable base for the ointment, and evenly distributed. An ointment has the advantage of not irritating, has good distribution and adhesion to the skin, does not inhibit gas exchange and sweat production so that its effectiveness is longer (Lestari et al., 2017).

Snakehead fish ointment has been shown to have a healing effect on cuts (Daisa et al., 2017). Snakehead fish (Channa striata) contains amino acids and fatty acids which are important in the synthesis of collagen fibers, especially glycine, during the wound healing process. It has a very high protein content compared to other types of freshwater fish. The protein content of snakehead fish reaches $25.5 \%$ with $6.22 \%$ albumin, which is quite high. Snakehead fish extract can significantly increase serum albumin levels and accelerate the wound healing process after surgery. The highest protein content of snakehead fish is found in the part of the meat which contains complete amino acids, both essential and non-essential (Prastari et al., 2017).

Honey has antibacterial effects, is useful as an antiseptic, inhibits the growth of Staphylococcus aureus bacteria, and accelerates the circulation process which affects the wound healing process (Fuadah et al., 2015). The nutritional content of kelulut honey is better than regular bee honey (Syaifudin, 2020). The advantages of kelulut honey are the presence of antioxidants that can break the chain reaction of free radicals; antimicrobials that can overcome bacterial contamination; high content of calcium, potassium, magnesium, sodium, and manganese; wound healing; anti-bacterial; antidiabetic; and anti-inflammatory (Halwany et al., 2020). Kelulut honey (Heterotrigona itama) has a high acidity (low $\mathrm{pH}$ ) ranging from 3.2 to 4.5 so that it can prevent the growth of microorganisms (Karnia et al., 2019). The combination of natural snakehead fish extract and kelulut honey is expected to provide a synergistic effect and increase the effectiveness in wound healing.

The ointment formulation that has been used in the orientation shows instability with the separation between the aqueous phase and the ointment base, so the researchers want to add excipients that can bind to the aqueous phase in the ointment preparation. The instability of medicinal products can result in a decrease until the loss of medicinal properties, can turn toxic, or change the appearance of the preparation (color, smell, taste, consistency) (Pratiwi et al., 2018). In this study, CMC-Na as a gelling agent was used to increase the viscosity of the ointment. A gelling agent is one of the ingredients that can increase the thickness of the dosage form through the binding mechanism of solvent molecules into the polymer network, thereby reducing movement and producing a higher system viscosity (Paye et al., 2019). CMC-Na is quite stable although it has hygroscopic properties and can absorb large amounts of water (> 50\%) under high humidity conditions. The gelling function of CMC-Na works at a concentration of 3-6\% (Rowe et al., 2009).

Based on the above exposure, this study conducted a trial of the addition of CMC-Na (3\%, $4.5 \%$, and $6 \%$ ) to the stability of snakehead fish extract and kelulut honey ointment. The preparation stability was tested using the accelerated stability method with a temperature of $40 \pm 2^{\circ} \mathrm{C}$ and a humidity of $75 \pm 5 \%$.

\section{MATERIALS AND METHODS \\ Materials}

The materials used in this research were snakehead fish (Channa striata), kelulut honey (Heterotrigona itama), adeps lanae (Wujiang Jinyu), methylparaben (Science Lab.), propylparaben (Golden Era), propylene glycol (The Dow Chemical Company USP NF Grade), CMC-Na (CV. Clorogreen), $\mathrm{NaOH}$ (Emsure $\left.{ }^{\circledR}\right)$, phenolphthalein indicator (Ph Eur), liquid paraffin (PT. Brataco), and aquadest. 


\section{Methods}

\section{Determinations}

The determination of snakehead fish (Channa striata) and kelulut honey (Heterotrigona itama) were done in the Biology Laboratory, Department of Biology, Faculty of Mathematics and Natural Sciences, Tanjungpura University, Pontianak, West Kalimantan.

\section{Preparation of snakehead fish extract}

The extraction process used in this research is wet rendering, which is boiling and pressing using water. The part of snakehead fish used is the meat part, while other parts such as skin, head, stomach contents, scales, and bones are not used. Three kilograms of snakehead fish (Channa striata) cleaned off the head and stomach contents, then steamed for 30 minutes in a pan at a temperature of $60-70^{\circ} \mathrm{C}$. The steamed meat is wrapped in a filter cloth then pressed with a hydraulic press to get the snakehead fish extract liquid. Snakehead fish extract was obtained as much as 650.6 grams $(21.69 \%$ of snakehead fish meat). The extract is stored in a container and covered with plastic wrap and aluminum foil (Eka and Rochima, 2016).

\section{Kelulut honey samples}

Kelulut honey (Heterotrigona itama) is harvested in the dry season to obtain honey with low water content. The stability of kelulut honey can be disturbed by the presence of excess water content (Putu et al., 2017).

\section{Preparation of ointments}

Ointment formulations can be seen in Table 1. The weight of ointment is for a single preparation. Adeps lanae is put into a mortar and crushed slowly until homogeneous and turns into yellowish-white. The mixture of methylparaben and propylparaben which has been dissolved in propylene glycol is added to the mortar that contained adeps lanae and stirred until homogeneous. Methylparaben and propylparaben function as the oil phase preservative, in this case adeps lanae. The extract of snakehead fish and kelulut honey is heated on a hot plate while stirring using a magnetic stirrer for 5-10 minutes until the temperature is $\pm 50-60^{\circ} \mathrm{C}$, then used to swell $\mathrm{CMC}-\mathrm{Na}$ in another heated mortar. The homogeneous mixture is then added to Adeps lanae and crushed until homogeneous. Each formula as much as 10 grams each put into 3 pots of ointment and stored in a modified climatic chamber with a temperature of $40^{\circ} \pm 2^{\circ} \mathrm{C} / \mathrm{RH} 75 \% \pm 5 \%$ (accelerated stability test).

Table 1. Ointment formulations (w/v)

\begin{tabular}{lclll}
\hline Ingredient & Control & F1 & F2 & F3 \\
\hline Snakehead fish extract & $30 \%$ & $30 \%$ & $30 \%$ & $30 \%$ \\
Kelulut honey & $30 \%$ & $30 \%$ & $30 \%$ & $30 \%$ \\
CMC-Na & - & $3 \%$ & $4.5 \%$ & $6 \%$ \\
Methylparaben & $0.18 \%$ & $0.18 \%$ & $0.18 \%$ & $0.18 \%$ \\
Propylparaben & $0.02 \%$ & $0.02 \%$ & $0.02 \%$ & $0.02 \%$ \\
Propylene glycol & $1.04 \%$ & $1.04 \%$ & $1.04 \%$ & $1.04 \%$ \\
Adeps lanae & $37.76 \%$ & $34.76 \%$ & $33.26 \%$ & $31.76 \%$ \\
\hline
\end{tabular}

Ointment sample testing was carried out on days $0,3,7,14,21$, and 28 . Stability tests were observed in the form of organoleptic, homogeneity, spreadability, adhesion, and protective power. The test was carried out three times replication. 


\section{Organoleptic test}

The effect of CMC-Na on the physical stability of the ointment visually in the presence of the influence of high temperature and humidity $\left(40^{\circ} \pm 2^{\circ} \mathrm{C} / \mathrm{RH} 75 \% \pm 5 \%\right)$ during the storage, could be determined from the organoleptic test. Organoleptic testing of preparations was carried out using the senses to describe its shape or consistency (e.g. solid, viscous, liquid), color (e.g. yellow, brown), and odor (e.g. aromatic, odorless). This test is also related to the convenience of using the ointment on the skin. A good ointment should have a pleasant odor, attractive color, and a soft texture to the skin (Daisa et al., 2017).

\section{Homogeneity test}

The stability of the homogeneity of the ointment against the influence of high temperature and humidity $\left(40^{\circ} \pm 2^{\circ} \mathrm{C} / \mathrm{RH} 75 \% \pm 5 \%\right)$ during the storage, could be determined from the homogeneity test. Homogeneity testing is done by applying 0.1 gram of ointment to the surface of the object-glass and then observing its homogeneity. A homogeneous ointment characterized by the absence of lumps on the result of basting, even structure, and a uniform color (Hasrawati et al., 2019).

\section{Spreadability test}

The distribution of the ointment on the skin and its stability against the effect of high temperature and humidity $\left(40^{\circ} \pm 2^{\circ} \mathrm{C} / \mathrm{RH} 75 \% \pm 5 \%\right)$ during the storage, could be determined from the spreadability test. The spreadability examination was carried out by placing $0.5 \mathrm{~g}$ of ointment in the middle between two petri on graph paper. Give a load of 150 grams and let stand for 60 seconds then re-record the diameter of the ointment that spreads by taking the diameter average length from several sides (Fujiastuti and Sugihartini, 2015). A good ointment has a spread value of 5 to $7 \mathrm{~cm}$ (Zukhri et al., 2018).

\section{Adhesion test}

The length of time the ointment was attached to the skin and its stability against the influence of high temperature and humidity $\left(40^{\circ} \pm 2^{\circ} \mathrm{C} / \mathrm{RH} 75 \% \pm 5 \%\right)$ during the storage, could be determined from the adhesion test. 0.25 grams of ointment is placed on an object-glass whose width has been determined, then another object-glass is placed on top of the ointment. A load of one kilogram is placed on the object-glass and left to stand for 5 minutes to compress the ointment between the objectglasses, then released. The 80 grams load is then hung on the object-glass and the time is recorded until the two glass objects are released (Pratimasari et al., 2015). The requirement for good ointment adhesion is not less than 4 seconds (Zukhri et al., 2018).

\section{Protection power test}

The protective ability of the ointment against the skin from external influence, especially base aqueous solution, could be determined from the protection power test. The protective power of the ointment is indicated by the absence of red stains after the addition of $\mathrm{NaOH}$. The protective power test was carried out by cutting filter paper $(10 \mathrm{x} 10 \mathrm{~cm})$, then wetted with a solution of PP (Phenolphthalein) as an indicator and dried then smeared with an ointment preparation. Another filter paper $(2.5 \times 2.5 \mathrm{~cm})$ is moistened with liquid paraffin on the edges and waited to dry so that an area of the filter paper is limited with liquid paraffin. Filter paper smeared with ointment was affixed under the filter paper bordered with liquid paraffin. The area is moistened with $\mathrm{NaOH}(0.1 \mathrm{~N})$ solution. Observations were made at 15, 30, 45, 60 seconds, 3, and 5 minutes (Susilowati and Wahyuningsih, 2014).

\section{Data Analysis}

The adhesion and spreadability test results of the ointment were statistically analyzed with normality and homogeneity tests using SPSS 21.0. One Way ANOVA test will be performed if the 
data is homogeneous $(\alpha \geq 0.05)$ and normally distributed $(\alpha \geq 0.05)$. If not, the statistical test was continued with the non-parametric Mann Whitney and Kruskal Wallis tests. The Post Hoc test is carried out if the One Way ANOVA test results show a significant difference between groups (Tyastirin and Hidayati, 2017). If the parametric or non-parametric test results are $\alpha \leq 0.05$, then the data is statistically considered to have a significant difference (Hariningtyas, 2015).

\section{RESULTS AND DISCUSSION}

The ointments in this study were formulated to have a good stability to extend their storage. The ointments were made in three various concentrations of CMC-Na (3\%, 4.5\%, and 6\%) and without $\mathrm{CMC}-\mathrm{Na}$ to compare which concentration of CMC-Na was the best in binding the aqueous phase to the ointment base. Snakehead fish extract (Channa striata) and kelulut honey (Heterotrigona itama) were the active ingredients used in this study.

\section{Organoleptic test results}

The organoleptic test results showed that all the ointments were yellowish-white and had a distinctive honey smell. This distinctive color and odor tend to be produced by the honey contained in the preparation, as well as the presence of yellowish-white adeps lanae. The control ointment had a very soft texture but experienced phase separation on the 7th day of storage, while the ointment containing CMC-Na had a denser texture and decreased consistency on the 21 st day. This shows the effect of CMC-Na in preventing the discharge of the aqueous phase in the ointment preparation.

The texture test results showed F3 (CMC-Na 6\%) had the densest ointment consistency compared to F2 (CMC-Na 4.5\%) and F1 (CMC-Na 3\%). This can be seen from the application of ointment to the skin. F3 is the formulation with the heaviest application on the skin compared to F2 and $\mathrm{F} 1$. This is because the higher the concentration of CMC-Na, the more hydrogen bridges can trap water, thus increasing the consistency (Belitz and Grosch, 1986). More hydrogen bonds will form as the concentration of CMC-Na increases and makes the system more rigid (Forestryana et al., 2020). This is consistent with other studies which state that the higher the concentration of CMC-Na, the denser the consistency of the resulting preparation is (Rohmani and Kuncoro, 2019).

The ointment with CMC-Na began to decreased consistency on day 21, where the texture of the preparation became softer. The whole ointment formulation becomes very gentle and the more easily applied to the skin. This decreased consistency was due to the ointment stability testing carried out at high temperatures and humidity $\left(40^{\circ} \pm 2^{\circ} \mathrm{C} / \mathrm{RH} 75 \% \pm 5 \%\right)$. High temperatures and humidity can be drawn into the system and increase the water content in the preparation, causing a decreased consistency. Water is no longer absorbed into CMC-Na and forms an elastic hydrogel formation as when making ointments, but increases the humidity or water content in the ointment preparation itself. This is because the CMC-Na matrix binds with adeps lanae forming a mass of ointment, no longer in its singular form.

\section{Homogeneity test results}

A homogeneous ointment characterized by the absence of lumps on the result of basting, even structure, and a uniform color (Hasrawati et al., 2019). The control formulation produced an inhomogeneous preparation on the 7th day which was marked by the presence of phase separation. Formulations 1,2, and 3 show the existence of phase separation in the climatic chamber on the 21st day of storage, but the phases of the preparations reunite after the preparation is removed from the climatic chamber and the temperature decreases. This phenomenon occurs because CMC-Na is a temperature-reversible gelling agent. These properties make the gel melt on heating and form the gel back on cooling (Supomo et al., 2015). This indicates that CMC-Na has an effect in increasing the stability of the ointment by binding to the aqueous phase and preventing it from leaving the ointment base. The hydrophilic part of CMC-Na can absorb the aqueous phase into the matrix and prevent it from moving freely (Fitriyaningtyas and Widyaningsih, 2015). 


\section{Spreadability test results}

The spreadability test results with 150 grams load showed that the ointment without CMC-Na (control formulation) had the highest dispersion of $5.36 \mathrm{~cm}$ on day 0 . This is due to the lowest consistency of other formulations. Ointment with CMC-Na 3\% (F1) had the highest average spreability on day 0 of $5.09 \mathrm{~cm}$, followed by CMC-Na $4.5 \%$ (F2) of $4.42 \mathrm{~cm}$ and CMC-Na 6\% (F3) of $3.69 \mathrm{~cm}$. The spreadability test was repeated three times and analyzed using the One Way ANOVA test. The average of the spreadability test results can be seen in Table 2 .

Table 2. The average test results of spreadability test

\begin{tabular}{|c|c|c|}
\hline Formulations & Test Day & $\bar{x} \pm \mathrm{SD}(\mathrm{cm})$ \\
\hline \multirow{6}{*}{ Control } & 0 & $5.36 \pm 0.17$ \\
\hline & 3 & $5.61 \pm 0.02 *$ \\
\hline & 7 & - \\
\hline & 14 & - \\
\hline & 21 & - \\
\hline & 28 & - \\
\hline \multirow{6}{*}{ F1 } & 0 & $5.09 \pm 0.04$ \\
\hline & 3 & $5.35 \pm 0.03 *$ \\
\hline & 7 & $5.50 \pm 0.03 *$ \\
\hline & 14 & $5.61 \pm 0.02 *$ \\
\hline & 21 & $5.78 \pm 0.03 *$ \\
\hline & 28 & $5.93 \pm 004^{*}$ \\
\hline \multirow{6}{*}{$\mathrm{F} 2$} & 0 & $4.42 \pm 0.04$ \\
\hline & 3 & $4.78 \pm 0.03 *$ \\
\hline & 7 & $4.99 \pm 0.05^{*}$ \\
\hline & 14 & $5.05 \pm 0.02 *$ \\
\hline & 21 & $5.21 \pm 0.02 *$ \\
\hline & 28 & $5.45 \pm 0.02 *$ \\
\hline \multirow{6}{*}{ F3 } & 0 & $3.69 \pm 0.03$ \\
\hline & 3 & $3.97 \pm 0.01 *$ \\
\hline & 7 & $4.04 \pm 0.04 *$ \\
\hline & 14 & $4.48 \pm 0.04 *$ \\
\hline & 21 & $4.99 \pm 0.05^{*}$ \\
\hline & 28 & $5.23 \pm 0.02 *$ \\
\hline
\end{tabular}

Description: $*$ = significantly increase in spreadability per test day

Ointment with CMC-Na 6\% (F3) has the lowest average spreadability compared to other formulations because it contains CMC-Na with the highest concentration. In contrast, ointments with CMC-Na 3\% (F1) had the highest average spreadability compared to ointments with CMC-Na $4.5 \%$ (F2) and 6\% (F3) because they contained CMC-Na with the lowest concentrations. This is in accordance with other studies which state that the higher the concentration of CMC-Na used, the higher the consistency, so that the dispersion will be lower (Shan and Wicaksono, 2018). The high 
consistency makes it difficult for the ointment to spread so that the result of spreadability is low (Arista and Paulina, 2013).

The control formulation that had undergone phase separation on the 7th day of storage was no longer tested for its spreadability stability. This is because the phase separation indicates that the preparation is unstable. All formulations experienced a significant increase in spreadability over 28 days of storage. The formulation with CMC-Na 3\% (F1) shows an ointment with spreadability that met criteria since day 0 .

\section{Adhesion test results}

The adhesion test results showed that all ointment formulations met the criteria for good ointment adhesion with an average adhesion is more than 4 seconds. The average adhesiveness from highest to lowest was F3, F2, F1, and the control formulation. These results are consistent with other studies which state that the higher the CMC-Na concentration used, the higher the adhesion of the resulting dosage (Rohmani and Kuncoro, 2019). This because CMC-Na can prevent the separation of the aqueous phase and cause an increase in adhesion (Baskara et al., 2020). The adhesion test was carried out for three replications and analyzed using the One Way ANOVA test. The average of the adhesion test results can be seen in Figure 1.

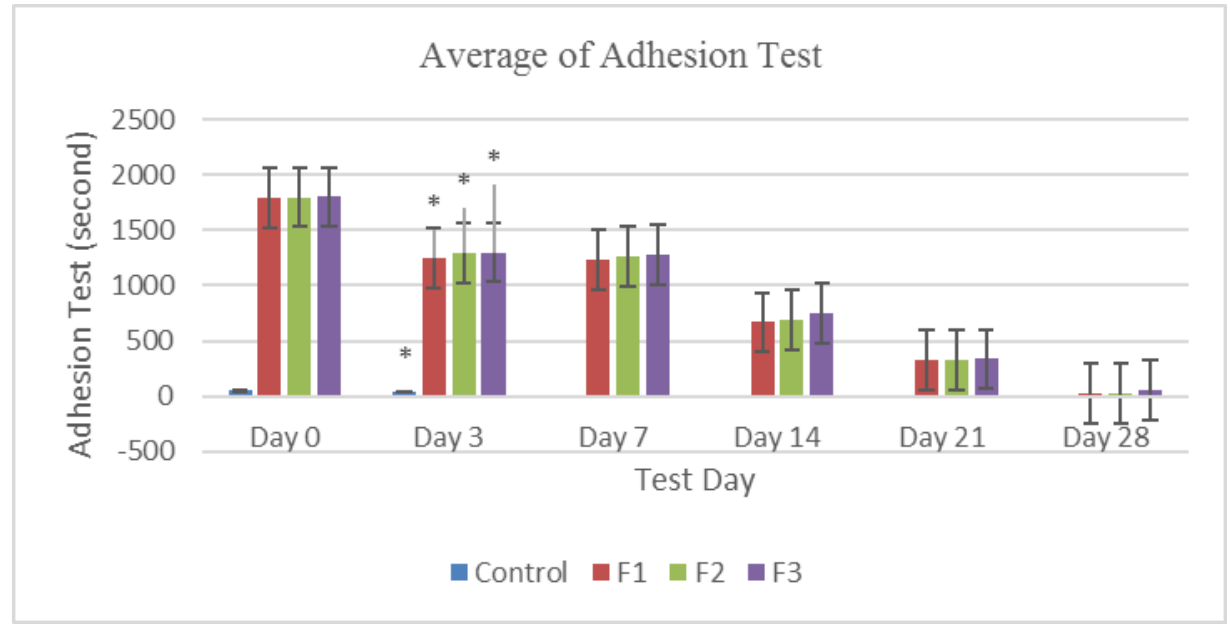

Figure 1. The average test results of adhesion test

Description: $*$ significantly reduction in adhesion per test day

The control formulation that had undergone phase separation on the 7th day of storage was no longer tested for its stickiness stability. This is because the phase separation indicates that the preparation is unstable. All formulations experienced a significant reduction in adhesion over 28 days of storage. However, all formulations still met the criteria for good adhesion values for ointments, with adhesion values of more than 4 seconds.

\section{Protection power test results}

Ointments with good protective power will not cause a red color when they are dropped with $\mathrm{NaOH}$ which indicates the ability of the ointment to protect the skin from external influences, in this case the presence of strong alkaline compounds. The results of the protective power test showed that all ointment formulations had good protective power as shown by the absence of red stains after being dripped with $\mathrm{NaOH}$. This result shows that all the produced ointments can protect the skin from water penetration. 


\section{CONCLUSION}

The results showed that CMC-Na 3\% was the optimum concentration in increasing the stability of snakehead fish extract and kelulut honey ointment preparation. CMC-Na has been shown to have an effect on the physical stability of the ointment by binding to the aqueous phase and increasing the consistency. CMC-Na prevented the ointment from experiencing phase separation, so its stability was increased compared to the formulation in the previous study. The ointment with a concentration of CMC-Na 3\% (F1) proved to meet the requirements of physical stability with an average spreadability of $5.09 \mathrm{~cm}$, an average adhesion of 1797.33 seconds, homogeneous, soft textured, and has good protective power.

\section{REFERENCES}

Arista, Y. N., \& Paulina, V. Y. (2013). Formulasi dan uji aktivitas gel antijerawat ekstrak umbi baku (Crinum asiaticum L.) terhadap Bakteri Staphylococcus aureus secara In Vitro. Jurnal Ilmiah Kefarmasian, 2(2), 18-26

Baskara, I. B. B., Suhendra, L., \& Wrasiasti, L. P. (2020). Pengaruh suhu pencampuran dan lama pengadukan terhadap karakteristik sediaan krim. Jurnal Rekayasa Dan Manajemen Argoindustri, 8(2), 200-209. https://doi.org/10.24843/JRMA.2020.v08.i02.p05

Belitz, H. D., \& Grosch, W. (1986). Food Chemistry. Springer Veralag Berlin Heldenberg.

Daisa, F., Andrie, M., \& Taurina, W. (2017). The effectiveness test of oil phase ointment containing snakehead fish (channa striata) extract on open stage ii acute wounded wistar strain male rats. Majalah Obat Tradisional, 22(2), 97. https://doi.org/10.22146/tradmedj.27920

Eka, B., \& Rochima, E. (2016). Pengaruh metode rendering terhadap karakteristik fisik , kimia dan organoleptik ekstrak kasar minyak ikan lele. Jurnal Perikanan Kelautan, VII(1), 1-5

Fitriyaningtyas, S. I., \& Widyaningsih, T. D. (2015). Pengaruh penggunaan lesitin dan cmc terhadap sifat fisik, kimia, dan organoleptik margarin sari apel manalagi (Malus sylfertris Mill) tersuplementasi minyak kacang tanah. Jurnal Pangan Dan Agroindustri, 3(1), 229

Forestryana, D., Surur Fahmi, M., \& Novyra Putri, A. (2020). Pengaruh jenis dan konsentrasi gelling agent pada karakteristik formula gel antiseptik ekstrak etanol $70 \%$ kulit buah pisang ambon. Lumbung Farmasi: Jurnal Ilmu Kefarmasian, 1(2), 45. https://doi.org/10.31764/lf.v1i2.2303

Fuadah, D. Z., Rachmania, D., \& Yudik, N. (2015). The effect of honey compress therapy toward skin wound healing for full thicknes loss on Rattus Norvegicus. Jurnal Ners Dan Kebidanan (Journal of Ners and Midwifery), 2(2), 103-107. https://doi.org/10.26699/jnk.v2i2.art.p103-107

Fujiastuti, T., \& Sugihartini, N. (2015). Sifat fisik dan daya iritasi gel ekstrak etanol herba pegagan (Centella asiatica L.) dengan variasi jenis gelling agent. Pharmacy, 12(01), 11-20. https://doi.org/10.1007/978-3-319-12715-6_10

Halwany, W., Hakim, S. S., Rahmanto, B., Wahyuningtyas, R. S., Siswadi, Andriani, S., \& Lestari, F. (2020). A simple reducing water content technique for stingless bee honey (Heterotrigona itama) in South Kalimantan. IOP Conference Series: Materials Science and Engineering, 935(1). https://doi.org/10.1088/1757-899X/935/1/012011

Hariningtyas, R. A. (2015). Pengaruh asimetri informasi terhadap senjangan anggaran pendahuluan. Jurnal Nominal, IV(2), 73-87

Hasrawati, A., Famir, Y., \& Mursyid, A. M. (2019). Formulasi dan evaluasi salep ekstrak daun Gulma Siam ( Chromolaena odorata L .) dengan variasi basis salep. As-Syifaa Jurnal Farmasi, 11(01), 55-60. https://doi.org/10.33096/ja.v11i1.514

Karnia, I., Hamidah, S., \& Rahmat, A. (2019). Pengaruh masa simpan madu kelulut (Trigona sp.) terhadap kadar gula pereduksi dan keasaman. Jurnal Sylva Scienteae, 02(6), 1094-1099.

Lestari, T., Yunianto, B., \& Winarso, A. (2017). Evaluasi mutu salep dengan bahan aktif temugiring, kencur dan kunyit. Jurnal Kebidanan Dan Kesehatan Tradisional, 2(1), 8-12. https://doi.org/10.37341/jkkt.v2i1.34

Paye, M., Barel, A., \& Maibach, H. (2019). Handbook of cosmetic science and technology. In CRC 
Press (Vol. 53, Issue 9). CRC Press.

Prastari, C., Yasni, S., \& Nurilmala, M. (2017). Characterization of snakehead fish protein that's potential as antihyperglikemik. Jurnal Pengolahan Hasil Perikanan Indonesia, 20(2), 413. https://doi.org/10.17844/jphpi.v20i2.18109

Pratimasari, D., Sugihartini, N., \& Yuwono, T. (2015). Evaluasi sifat fisik dan uji iritasi sediaan salep minyak atsiri bunga cengkeh dalam basis larut air. Jurnal Ilmiah Farmasi, 11(1), 9-15. https://doi.org/10.20885/iif.vol11.iss1.art2

Pratiwi, L., Fudholi, A., Martien, R., \& Pramono, S. (2018). Uji stabilitas fisik dan kimia sediaan SNEDDS (Self-nanoemulsifying Drug Delivery System) dan nanoemulsi fraksi etil asetat kulit manggis (Garcinia mangostana L.) physical and chemical stability test of SNEDDS (Selfnanoemulsifying Drug Delivery System) a. Traditional Medicine Journal, 23(2), 84-90. https://doi.org/10.22146/mot.28533

Putu, N., Savitri, T., Hastuti, E. D., Widodo, S., \& Suedy, A. (2017). Kualitas madu lokal dari beberapa wilayah di Kabupaten Temanggung. Buletin Anatomi Dan Fisiologi, 2(1), 58-66. https://doi.org/10.14710/baf.2.1.2017.58-66

Rohmani, S., \& Kuncoro, M. A. A. (2019). Uji stabilitas dan aktivitas gel handsanitizer ekstrak daun kemangi. Journal of Pharmaceutical Science and Clinical Research, 01, 16-28. https://doi.org/10.20961/jpscr.v4i1.27212

Rowe, R., Sheskey, P., \& Quinn, M. (2009). Handbook of Pharmaceutical Excipients. In London: Vol. E.28 (6th editio)

Shan, W. Y., \& Wicaksono, I. A. (2018). Artikel tinjauan: formulasi gel ekstrak kulit manggis (Garnicia mangostana) dengan variasi konsentrasi basis. Farmaka, 16(1), 108-116

Supomo, Sukawaty, Y., \& Baysar, F. (2015). Formulasi gel hand sanitizer dari kitosan dengan basis natrium karboksimetilselulosa. Jurnal Ilmiah Manuntung, 1(April), 31-37. https://doi.org/10.51352/jim.v1i1.8

Susilowati, E. P., \& Wahyuningsih, S. S. (2014). Optimasi sediaan salep yang mengandung eugenol dari isolasi minyak cengkeh (Eugenia caryophylatta Thunb.). Indonesian Journal On Medical Science, 1(2), 29-34

Syaifudin, S. M. (2020). Budidaya pakan lebah trigona sp. dengan apiculture agroforestry system di kelurahan Anjungan Melancar, Kecamatan Anjungan Kabupaten Mempawah. Jurnal Ilmiah Pangabdhi, 6(1), 17-24. https://doi.org/10.21107/pangabdhi.v6i1.6932

Tyastirin, E., \& Hidayati, I. (2017). Statistik parametrik untuk penelitian kesehatan. In Program Studi Arsitektur UIN Sunan Ampel. Program Studi Arsitektur UIN Sunan Ampel

Zukhri, S., Murni Sari Dewi, K., Hidayati, N., Muhammadiyah Klaten, S., \& Muhamamdiyah Klaten, S. (2018). Uji sifat fisik dan antibakteri salep ekstrak daun katuk (sauropus androgynus (l) merr.). Jurnal Ilmiah Kesehatan (JIK), XI(1), 303-312 